\title{
KAJIAN EKSPERIMENTAL EFISIENSI DAN KARAKTERISTIK PRODUKSI OZON BERDASARKAN VARIASI PANJANG DAN LAJU ALIR REAKTOR DIELECTRIC BARRIER DISCHARGE PLASMA (DBDP) BERBAHAN BAJA ANTI KARAT
}

\section{EXPERIMENTAL STUDY OF EFFICIENCY AND CHARACTERISTICS OF OZONE PRODUCTION BASED ON THE VARIATION OF STAINLESS STEEL BASED DIELECTRIC BARRIER DISCHARGE PLASMA (DBDP) REACTOR'S LENGTH AND FLOWING RATE}

\author{
Suraidin $^{1, \mathrm{a}}$ dan Muhammad Nur ${ }^{2, \mathrm{~b}}$ \\ ${ }^{1}$ Jurusan Magister Ilmu Fisika, Universitas Diponegoro Semarang \\ ${ }^{2}$ Jurusan Fisika, Universitas Diponegoro Semarang \\ J1. Prof. H. Soedarto, SH, Tembalang. Kota Semarang
}

e-mail: ${ }^{a}$ suraidin@st.fisika.undip.ac.id dan ${ }^{\mathrm{b}} \mathrm{m}$. nur@undip.ac.id

\begin{abstract}
Abstrak
Penelitian ini membahas kajian reaktor ozon dengan dielectric barrier discharge plasma (DBDP): variasi panjang elektroda stainless steel. Konsentrasi ozon dihasilkan dengan melakukan variasi tegangan mulai dari 3-5 kV dan variasi laju alir dari 2, 3, 4, 5, 6, 8, sampai 10 L/menit. Reaktor ozon yang digunakan sebagai pembangkit ozon mempunyai konfigurasi kerangka silinder-silinder. Elektroda dalam (kerangka silinder) terbuat dari stainless stell, sedangkan elektroda luar (silinder) terbuat dari lempengan seng dan bahan dielektrik yang digunakan adalah pyrex. Reaktor diberi tegangan tinggi AC dengan frekuensi $16 \mathrm{kHz}$. Penelitian ini menggunakan lima variasi panjang reaktor ozon yaitu 5, 10, 15, 20, dan $25 \mathrm{~cm}$. Untuk menentukan konsentrasi ozon pada setiap reaktor yang berbeda, maka ozon yang dihasilkan diserap dalam larutan KI selanjutnya dititrasi dengan natrium thiosulfat. Hasil penelitian menunjukan bahwa semakin panjang elektroda yang digunakan maka konsentrasi ozon yang dihasilkan semakin tinggi, yakni mulai dari 384 sampai dengan 634 ppm untuk laju alir 2 L/menit, sedangkan semakin besar laju alir gas oksigen maka konsetrasi yang dihasilkan semakin kecil, yakni mulai dari 624 sampai dengan 134.4 ppm untuk panjang reaktor $25 \mathrm{~cm}$. Selain itu, semakin tinggi tegangan yang diberikan maka konsentrasi ozon akan semakin meningkat, yakni dengan tegangan 3 sampai 5 kV menghasilkan konsentrasi dari 480 sampai dengan 624 ppm.
\end{abstract}

Kata Kunci: Ozon, Dielectric Barrier Discharge Plasma (DBDP), konsentrasi, reaktor, elektroda.

\begin{abstract}
This study reported experimental investigations of the ozone reactor with dielectric barrier discharge plasma (DBDP): variation of the stainless steel electrode length. The concentrations of ozone had calculated with variations of voltage (from 3 to $5 \mathrm{kV}$ ) and flowing rate (i.e. 2, 3, 4,5,6, 8 and $10 \mathrm{~L} / \mathrm{min}$ ). The reactor of ozone used for producing ozone has a frame with cylinder-cylinder configuration. The inner electrode (cylindrical) was made of stainless steel, the outer electrodes (cylindrical) made of slab zinc and dielectric materials used are Pyrex. AC high voltage was used as a power supply with the
\end{abstract}


frequency of $16 \mathrm{kHz}$. This research had been conducted with five variations of reactor's length of 5, 10, 15, 20, and $25 \mathrm{~cm}$. The ozone concentration was determined with KI and then titrated using sodium thiosulphate. The results showed that the longer electrode, the higher concentration of ozone is generated, ranging from 384 up to 634 ppm for the flow rate of $2 \mathrm{~L} / \mathrm{min}$, while the greater the flowing rate of oxygen gas, the smaller concentration that produced, ranging from 624 up to 134.4 ppm for 25 $\mathrm{cm}$ reactor length. Moreover, the higher the voltage applied, the higher concentration of ozone would increase, i.e., with the voltage of 3 to $5 \mathrm{kV}$, would be produced a concentration of 480 up to $624 \mathrm{ppm}$.

Keywords: Ozone, Dielectric Barrier Discharge Plasma (DBDP), concentration, reactor, electrodes.

Copyright@2016 Jurusan Fisika FMIPA Universitas Negeri Surabaya

\section{PENDAHULUAN}

Ozon pertama kali ditemukan oleh peneliti eropa bernama C.F. Schonbein pada tahun 1839. Ia mengidentifikasi bau yang timbul pada anoda selama elektrolisis air sebagai senyawa baru yang diberi nama ozon. Ozon pertama kali digunakan secara komersial pada tahun 1907 dalam menyediakan air yang baik dan pada tahun 1910 di St. Petersburg [1].

Ozon terdiri dari atom oksigen dengan simbol kimia $\mathrm{O}_{3}$. Ozon merupakan molekul yang relatif tidak stabil dibandingkan dengan oksigen $\mathrm{O}_{2}$ dan sangat relatif. Ozon dapat dibangkitkan dengan menggunakan radiasi ultaviolet reaksi opiocmical dan dielectrik barrier discharge (DBD). DBD saat ini diketahui sebagai metode yang paling efektif sebagai pembangkit ozon [2].

DBD merupan jenis plasma nonthermal yang umumnya terdiri atas dua elektroda yang dipisahkan oleh celah beberapa milimeter dan ditutupi dengan lapisan dielektrik. Dimana elektroda dihubungkan dengan tegangan tinggi AC (alternative current). Dielekrik berfungsi sebagai pembatas arus, mencegah pembentuk spark dan mendistribusikan discharge secara merata di seluruh daerah elektroda [3].

Sistem DBD umumnya terdiri atas power supply, elektroda dan penghalang dielektrik.
Menurut frekuensi operasi power supply DBD menggunakan alternative current (AC), radio frekuensi (RF), dan mode pulsa. Power supply dan jenis reaktor memiliki efek besar pada karakteristik DBD. Jenis reaktor dapat diklasifikasikan dengan konfigurasi elektroda, bahan elektroda bahan penghalang dielektrik dan adanya katalis antara elektroda. Adapun penghalang dielektrik, digunakan bahan sebagai lapisan isolasi adalah kaca, kuarsa, keramik, dan lapisan polimer sebagai lapisan isolasi. Jenis bahan, ketebalan dan struktur permukaan dari bahan dielektrik dapat mempengaruhi discharge plasma [4].

Ozon secara komersial dihasilkan dengan melewatkan molekul oksigen melalui muatan listrik. Dengan demikian, molekul oksigen terbagi menjadi dua gugus atom oksigen yang sangat relatif. Bila oksigen bebas $\left(\mathrm{O}^{*}\right)$ bertemu dengan $\mathrm{O}_{2}$ maka akan terjadi penggabungan sehingga membentuk molekul $\mathrm{O}_{3}$ yang sangat tidak stabil [1].

Pada 2014 Teke dkk., melakukan penelitian produksi ozon dalam DBDP terkait reaktor ozon laju panjang alir udara, reaktor ozon dibangkitkan dengan konfigurasi elektroda spiral silinder, elektroda spiral dibuat dari kawat tembaga berdiameter 1,5 $\mathrm{mm}$ dengan panjang lilitan $50 \mathrm{~mm}$, sedangkan elektroda silinder dari lembaran tembaga dan bahan dielektrik berupa pyrex. Hasil penelitiannya menunjukan bahwa konsentrasi ozon 
meningkat dengan meningkatnya tegangan dan panjang reaktor, sedangkan konsentrasi ozon semakin kecil dengan ditingkatkannya laju alir udara.

Tembaga adalah logam keperakan, dengan daya hantar yang tinggi antara semua logam-logam asli, meskipun tembaga mempunyai ketahanan karat lebih baik dari baja, tetapi dapat juga berkarat atau teroksidasi, dalam hal ini daya hantar listriknya akan menurun. Dengan demikian material tembaga kurang cocok sebagai reaktor ozon, dalam penelitian ini akan digunakan material baja anti karat (standless steel). Sebagai elektroda dalam reaktor ozon karakteristik terkait panjang elektroda aktif maupun elektroda pasif dan laju alir udara akan dikaji disini.

\section{METODE PENELITIAN}

Reaktor dielectric barrier discharge (DBD) yang digunakan untuk menghasilkan ozon di buat di Center for Plasma Research FSM UNDIP.

\section{Alat dan Bahan}

Alat-alat yang digunakan dalam penelitian ini antara lain amperemeter, flowmeter, osiloskop, tabung oksigen, probe, tegangan tinggi AC, gelas ukur, dan selang udara. Bahan yang digunakan dalam perakitan reaktor ozon yaitu gelas pyrex sebagai penghalang dielektrik, stainless steel sebagai elektroda dalam yang berbentuk rangka silinder, dan lempengan seng sebagai elektroda luar yang berbentuk silinder.

\section{Prosedur Penelitian}

Reaktor ozon dibuat dengan menggunakan metode DBDP yang panjang elektroda dalamnya divariasi antara $5 ; 10 ; 15 ; 20$; dan $25 \mathrm{~cm}$. Setiap panjang elektroda dalam yang berbeda diberi tegangan dan laju alir oksigen yang sama sehingga diperoleh konsentrasi ozon sebagai fungsi tegangan dan laju alir oksigen, sumber tegangan dengan frekwensi $16 \mathrm{kHz}$ digunakan adalah tegangan tinggi AC (Teke dkk, 2014), yang divariasi antara 2; 3; 4; dan $5 \mathrm{kV}$, sedangkan laju alir oksigen divariasi antara $2 ; 3 ; 4 ; 5 ; 6 ; 8$, dan $10 \mathrm{~L} /$ menit.

\section{Pembuatan Reaktor Ozon DBD}

Generator DBD menggunakan elektroda konfigurasi silinder dan rangka silinder, elektroda dalam berbentuk rangka silinder yang berbahan stainless steel dengan jenis Ornamen tipe ss 201 dengan diameter $40 \mathrm{~mm}$ dan elektroda luar berbentuk silinder terbuat dari lempengan seng, dan barrier yang digunakan adalah kaca berbahan pyrex berbentuk silinder dengan diameter $50 \mathrm{~mm}$ dan tebal $1.1 \mathrm{~mm}$. Skema reaktor ditunjukkan pada Gambar 1.

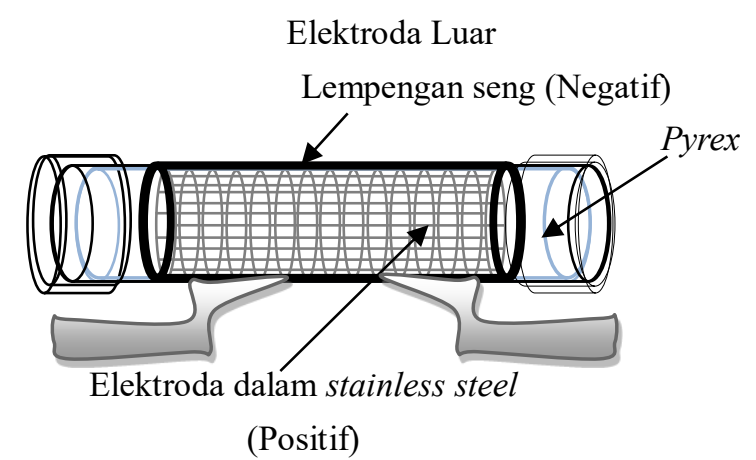

Gambar 1. Reaktor Ozon DBD

Elektroda dalam yang digunakan pada pembuatan generator ozon ini terbuat dari stainless steel. Pemilihan stainless steel didasari oleh karakteristiknya yang tahan terhadap karat serta sifat mekanis yang baik.

Elektroda dalam pada reaktor berbentuk kerangka silinder terbuat beberapa cincin berbahan stainless steel berdiameter $40 \mathrm{~mm}$ dengan tebal $2 \mathrm{~mm}$, divariasi panjang antara 5 , 10, 15, 20, dan $25 \mathrm{~cm}$. Untuk skema elektroda dalam pada reaktor ozon seperti yang ditunjukkan pada gambar 2 berikut: 


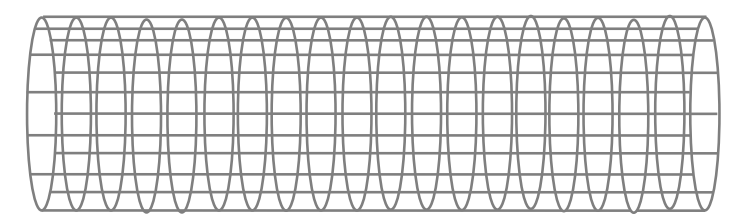

Gambar 2. Elektroda Dalam pada Reaktor DBD

\section{Rancangan Eksperimen dan Pengukuran Konsentrasi Ozon}

Skema susunan peralatan penelitian ditunjukan pada Gambar 3.3.

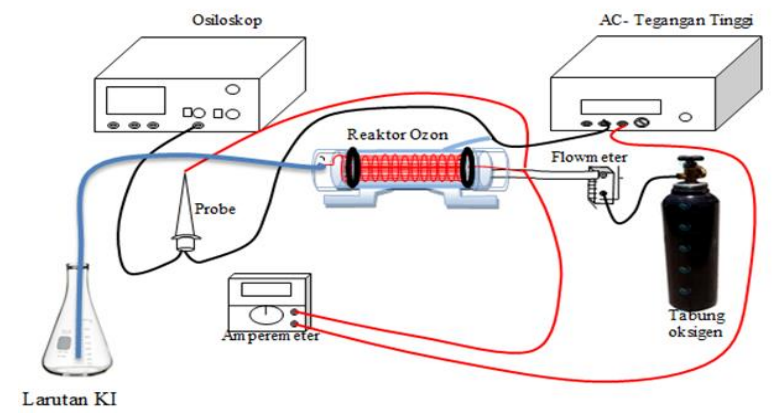

Gambar 3. Skema Susunan Peralatan dalam Penelitian

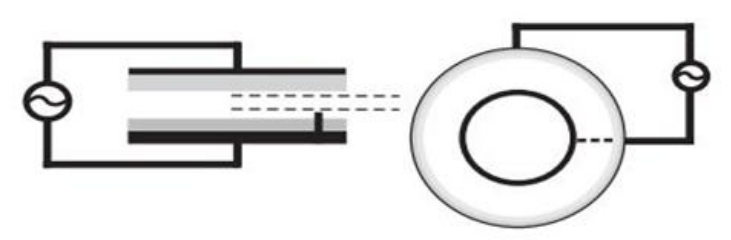

(a)

(b)

Gambar 4. Bentuk Konfigurasi Elektroda Lucutan Plasma Penghalang Dielektrik, (a) Geometri Elektroda Tampak Samping; (b) Geometri Elektroda Tampak Depan.

Reaktor DBD menggunakan elektroda dengan konfigurasi silinder dan kerangka silinder, elektroda dalam berbentuk kerangka silinder yang terbuat dari cincin berbahan stainless steel, diameter kerangka silinder masingmasing sebesar $40 \mathrm{~mm}$, elektroda luar berbentuk silinder terbuat dari lempengan seng dengan diameter $52 \mathrm{~mm}$, dan barrier yang digunakan adalah kaca berbahan pyrex dengan tebal $1,1 \mathrm{~mm}$ dan panjang $440 \mathrm{~mm}$. Setiap panjang reaktor diberi tegangan yang bervariasi dan sama sehingga diperoleh konsentrasi ozon sebagai fungsi tegangan dan laju. Sumber tegangan yang berupa tegangan tinggi AC yang bervariasi, yaitu 2, 3, 4, dan 5 $\mathrm{kV}$, sedangkan laju alir oksigen yang digunakan yaitu $2 ; 3 ; 4 ; 5 ; 6 ; 8$, dan 10 L/menit.

\section{Pengukuran Ozon}

Pengukuran konsentrasi ozon dimulai dengan membuat pengikat ozon terdiri dari $2 \mathrm{~g}$ senyawa KI (kalium iodida) yang dilarutkan ke dalam aquades $100 \mathrm{~mL}$. Adapun konsentrasi senyawa KI sebanyak 2 g dapat dihitung sebagai berikut:

$$
\begin{aligned}
\text { Konsentrasi } K I & =\frac{2 g \times \frac{\mathrm{mol}}{\mathrm{mr}}}{100 \mathrm{~mL}} \\
& =\frac{2 \mathrm{~g} \times \frac{\mathrm{mol}}{72 \mathrm{~g}}}{100 \mathrm{~mL}}
\end{aligned}
$$

Konsentrasi $K I=\frac{0.027 \mathrm{~mol}}{100 \mathrm{~mL}}$

atau

Konsentrasi $K I=0.27 \frac{\mathrm{mol}}{\mathrm{L}}$

Langkah selanjutnya mempersiapkan larutan $\mathrm{Na}_{2} \mathrm{~S}_{2} \mathrm{O}_{3}$ (natrium thiosulfat) $0.4 \mathrm{M}$ dan mempersiapkan amilum. Selanjutnya sebanyak $200 \mathrm{~mL}$ larutan $\mathrm{KI}$ dimasukan ke dalam labu Erlenmayer dan labu Erlenmeyer ditutup dengan menggunakan aluminium foil. Setelah itu larutan $\mathrm{Na}_{2} \mathrm{~S}_{2} \mathrm{O}_{3}$ dimasukan ke dalam buret. Setelah persiapan selesai, ozon dari reaktor dimasukan ke dalam larutan KI. Larutan yang semula berwarna bening akan berubah menjadi kuning. Untuk indikator perubahan warna dalam titrasi, ditambahkan amilum pada larutan yang mengandung ozon tersebut. Larutan yang berwarna kuning akan berubah warna menjadi biru muda - biru tua tergantung konsentrasi ozon. Larutan yang berwarna biru tersebut dititrasi dengan menggunakan larutan $\mathrm{Na}_{2} \mathrm{~S}_{2} \mathrm{O}_{3}$, sampai warna larutan KI kembali menjadi bening. Konsentrasi ozon adalah sebanding dengan volume larutan $\mathrm{Na}_{2} \mathrm{~S}_{2} \mathrm{O}_{3}$ yang digunakan 
untuk titrasi [5][6]. Konsentrasi ozon dapat dihitung menggunakan rumus:

$C_{O_{3}}=\frac{M r \cdot V \cdot N}{V_{O_{2}} \cdot e}$

$M r$ adalah massa molekul relatif ozon, $V$ volume titrat $\mathrm{Na}_{2} \mathrm{~S}_{2} \mathrm{O}_{3}, N$ konsentrasi natrium thiosulfat, dan $e$ suhu standar per suhu terukur [6].

\section{HASIL PENELITIAN DAN DISKUSI}

\section{Pengaruh Tegangan Terhadap Konsentrasi}

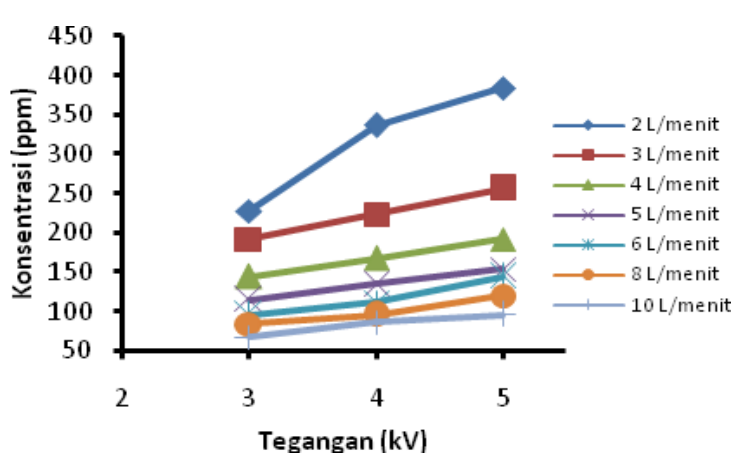

(a)

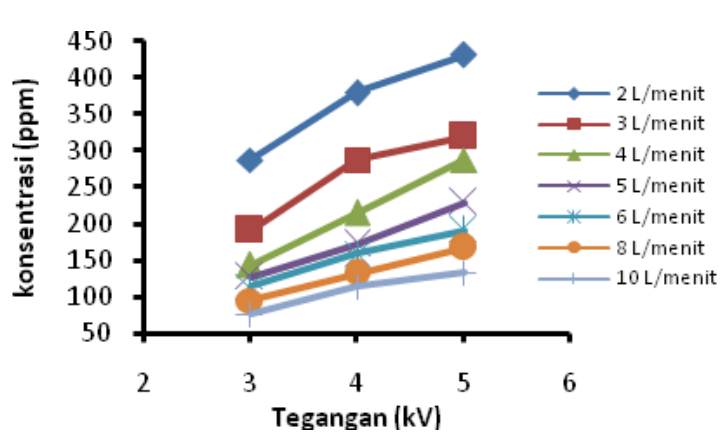

(c)

\section{Ozon.}

Pengaruh tegangan terhadap konsentrasi ozon dengan panjang elektroda yang berbeda dapat dilihat pada gambar 5. Tegangan merupakan salah satu yang dapat mempengaruhi terjadinya konsentrasi ozon pada penelitian ini, semakin meningkatnya tegangan yang diberikan maka beda potensial antara kedua elektroda akan semakin tinggi sehingga konsentrasi ozon yang dihasilkan semakin tinggi, ini sebanding dengan penelitian yang dilakukan oleh [7].

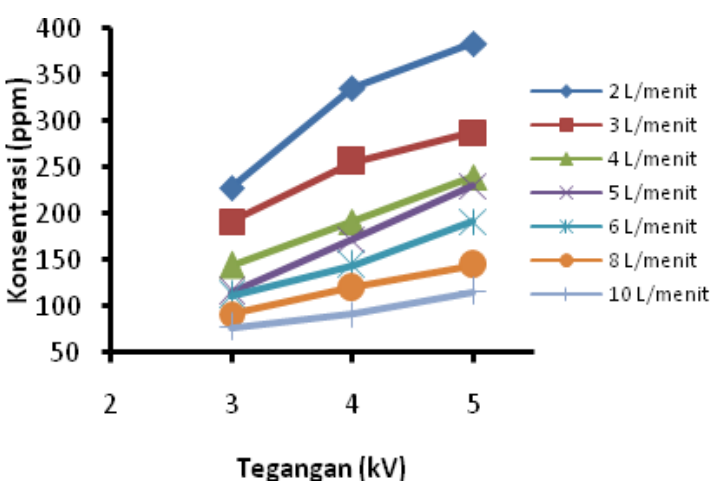

(b)

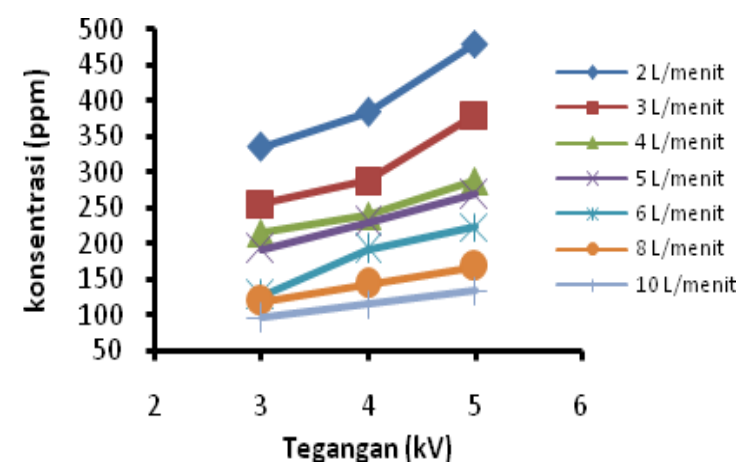

(d)

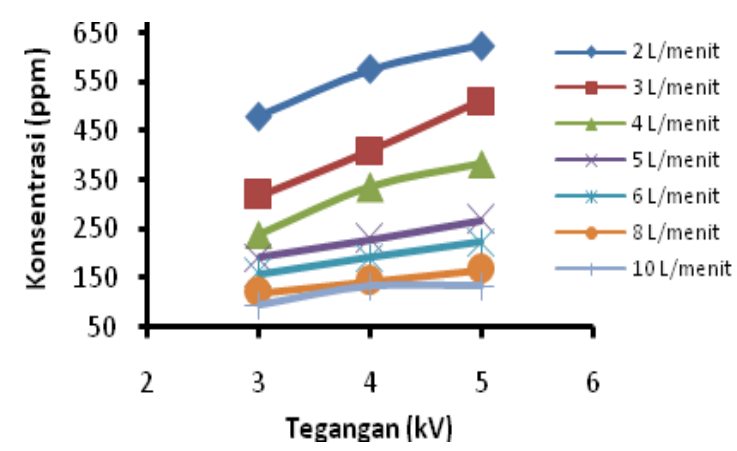

(e)

Gambar 5. Grafik Konsentrasi Ozon dengan Panjang Elektroda Dalam pada Reaktor DBDP (a) $5 \mathrm{~cm}$; (b) $10 \mathrm{~cm}$; (c) $15 \mathrm{~cm}$; (d) $20 \mathrm{~cm}$; dan (e) $25 \mathrm{~cm}$ sebagai Fungsi Tegangan dengan Laju Alir Oksigen. Konsentrasi ozon sebagai fungsi tegangan untuk laju alir oksigen yang berbeda dan 
pada panjang elektroda dalam yang berbeda, tegangan yang diberikan bervariasi antara 3-5 $\mathrm{kV}$ dan panjang elektroda dalam pada reaktor antara $5 ; 10 ; 15 ; 20$; dan $25 \mathrm{~cm}$, sedangkan laju alir oksigen yang diberikan 2 ; $3 ; 4 ; 5 ; 6 ; 8$; dan 10 L/menit. Untuk membedakan konsentrasi ozon pada setiap elektroda dalam yang berbeda, maka ozon yang keluar diukur menggunakan larutan kimia KI yang dilarutkan menggunakan aquades dan setelah dititrasi menggunakan NatriumThiosulfat.

Tegangan yang sama antara 3-5 kV diberikan pada reaktor dengan panjang elektroda dalam yang berbeda, untuk reaktor dengan panjang elektroda $5 \mathrm{~cm}$, konsentrasi yang terkecil didapatkan pada tegangan yang paling rendah yaitu $3 \mathrm{kV}$ diperoleh konsentrasi ozon sebesar 67,2 ppm dan konsentrasi ozon tertinggi didapatkan dengan tegangan maksimum yaitu $5 \mathrm{kV}$ konsentrasi ozon yang diperoleh sebesar 384 ppm. Perlakuan yang sama dilakukan pada reaktor dengan panjang elektroda $10 \mathrm{~cm}$, konsentrasi ozon minimum didapatkan pada tegangan yang paling rendah yaitu $3 \mathrm{kV}$ diperoleh konsentrasi ozon sebesar 76.8 ppm dan konsentrasi ozon maksimumnya berada pada tegangan maksimum $5 \mathrm{kV}$ sebesar 384 ppm, untuk reaktor dengan panjang elektroda $15 \mathrm{~cm}$, konsentrasi minimum berada pada tegangan yang paling renda $3 \mathrm{kV}$ sebesar 76.8 dan konsentrasi maksimumnya berada pada tegangan $5 \mathrm{kV}$ sebesar 432 ppm. Reaktor dengan panjang elektroda $20 \mathrm{~cm}$ didapatkan konsentrasi ozon minimumnya pada tegangan yang rendah pula yaitu $3 \mathrm{kV}$ sebesar $96 \mathrm{ppm}$ dan konsentrasi maksimumnya didapatka pada tegangan maksimum yaitu $5 \mathrm{kV}$ sebesar 480 ppm, dan reaktor dengan panjang elektroda $25 \mathrm{~cm}$ didapatan konsentrasi ozon minimum pada elektroda yang rendh yaitu $3 \mathrm{kV}$ sebesar 96 ppm dan konsentrasi maksimum didapatkan pada tegangan maksimum yaitu $5 \mathrm{kV}$ sebesar 624 ppm. Berdasarkan hasil yang diperoleh seperti yang ditunjukkan pada gambar 5 tegangan sangat mempengaruhi konsentrasi ozon, semakin tinggi tegangan yang diberikan maka konsentrasi ozon akan semakin meningkat.

Tegangan merupakan salah satu yang dapat mempengaruhi terjadinya konsentrasi ozon pada penelitian ini, semakin meningkatnya tegangan yang diberikan maka beda potensial antara kedua elektroda akan semakin tinggi. Hal ini disebabkan oleh udara yang berada dalam reaktor. Semakin tingginya tegangan maka molekul-molekul udara dalam reaktor akan lebih banyak, sehingga semakin banyak molekul-molekul yang bertumbukan. Hasil yang sama juga diperoleh oleh Nur dkk., 2014[7].

\section{Pengaruh Panjang Elektroda Tehadap Konsentrasi Ozon}

Pada penelitian ini menggunakan lima variasi panjang elektroda dalam pada reaktor DBDP antara $5 ; 10 ; 15 ; 20$; dan 25 $\mathrm{cm}$. Gambar 6 menunjukkan bahwa panjang elektroda pada reaktor dapat mempengaruhi konsentrasi ozon yang terbentuk. 


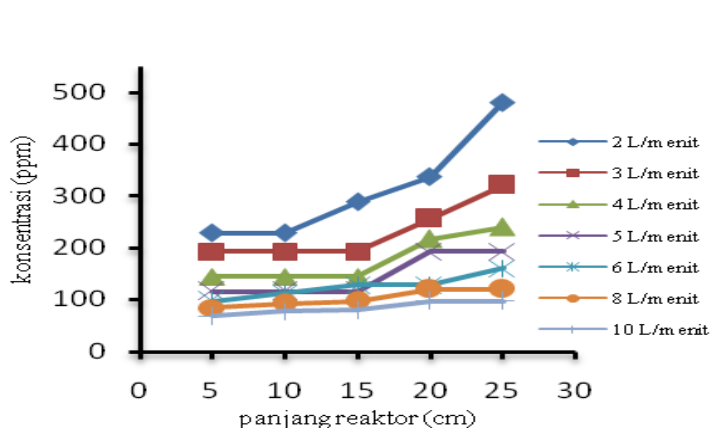

(a)

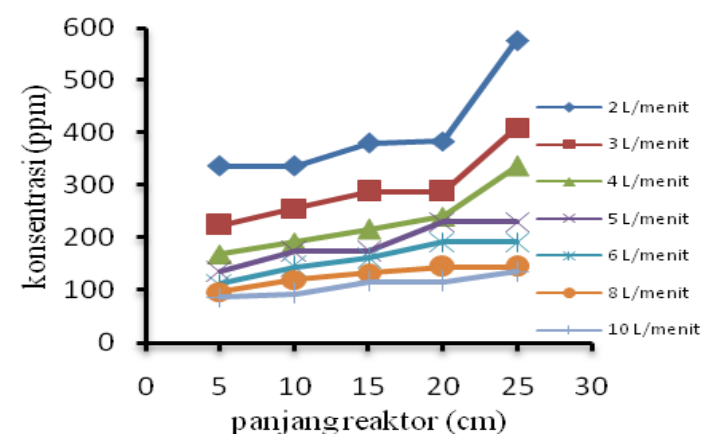

(b)

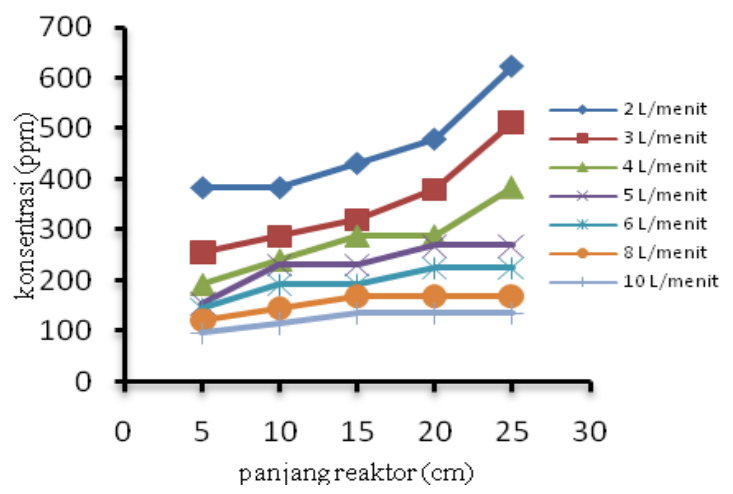

(c)

Gambar 6. Konsentrasi Ozon sebagai Fungsi Panjang Elektroda untuk Tegangan yang Berbeda (a) $3 \mathrm{kV}$; (b) $4 \mathrm{kV}$; (c) $5 \mathrm{kV}$.

Dari gambar 6 dapat dilihat bahwa elektroda yang panjang dapat menghasilkan konsentrasi ozon yang besar. Dari semua eksperimen untuk laju alir oksigen dengan elekroda yang panjang $25 \mathrm{~cm}$ selalu lebih besar konsentrasi ozon yang dihasilkan dibandingkan elektroda yang rentan lebih pendek. Fenomena ini bergantung pada waktu tinggal moleku-molekul udara di dalam reaktor. Konsentrasi ozon maksimum yang diperoleh dari reaktor ozon dengan panjang elektroda $5 \mathrm{~cm}$ sebesar $384 \mathrm{ppm}$, panjang elektroda $10 \mathrm{~cm}$ konsentrasi sebesar 384 ppm, panjang elektroda $15 \mathrm{~cm}$ konsentrasi sebesar 432 ppm, panjang elektroda $20 \mathrm{~cm}$ sebesar $480 \mathrm{ppm}$, dan panjang elektroda $25 \mathrm{~cm}$ sebesar $624 \mathrm{ppm}$.

\section{Pengaruh Laju Alir Oksigen Terhadap Konsentrasi}

Pada penelitian ini dilakukan beberapa variasi laju alir oksigen, yaitu antara $2 ; 3 ; 4$; 5; 6; 8 dan 10 L/Menit. Pada gambar 4.8 menunjukkan konsentrasi ozon pada reaktor dengan panjang elektroda $25 \mathrm{~cm}$, semakin besar laju alir maka konsentrasi akan semakin menurun, hasil yang sama juga didapatkan oleh [4].

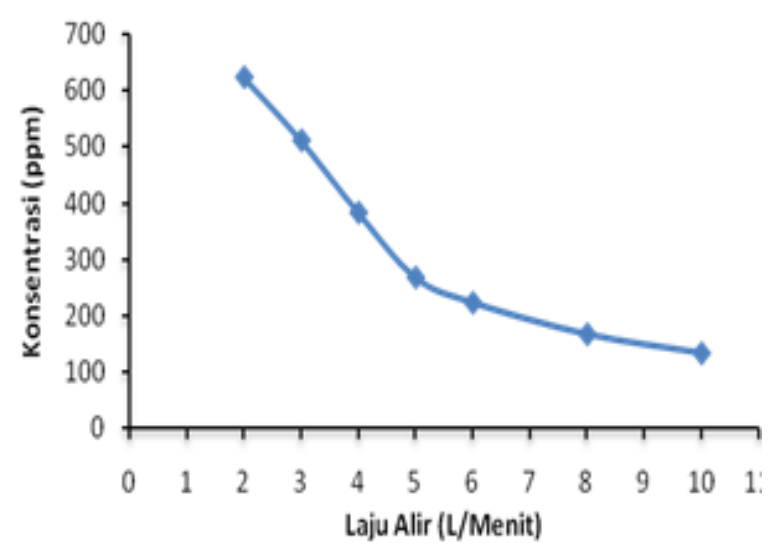

Gambar 7. Konsentrasi Ozon sebagai Fungsi Laju Alir pada Reaktor dengan Panjang Elektroda 25 cm dan Tegangan $5 \mathrm{kV}$.

Pada gambar 7 menunjukkan bahwa konsentrasi ozon dipengaruhi juga oleh laju 
alir oksigen yang diberikan, semakin besar laju alir yang diberikan maka konsentrasi yang dihasilkan akan semakin menurun, fenomena ini bergantung pada waktu tinggal molekul-molekul udara dalam reaktror, laju alir yang lebih besar akan mendorong keluar molekul-molekul udara yang berada dalam dengan cepat, sehingga waktu tinggal molekul-molekul udara di dalam reaktor lebih cepat, keadaan molekul-molekul yang sangat singkat ini akan menyebabkan molekul-molekul udara tidak mengalami proses tumbukan yang lebih lama dan molekul-molekul gas penyusun udara hanya sedikit yang mengalami proses ionisasi, disosiasi maupun rekombinasi untuk membentuk ozon, sehingga ozon yang dihasilkan relatif kecil.

\section{KESIMPULAN}

Dari hasil pembahasan pada penelitian dapat ditarik beberapa kesimpulan, antara lain sebagai berikut: (1) Konsentrasi ozon selalu lebih tinggi dengan laju alir oksigen yang lebih kecil, yaitu $2 \mathrm{~L} /$ menit, yakni sebesar 624 ppm dan konsentrasi ozon naik sebanding dengan naiknya tegangan $5 \mathrm{kV}$; (2) Panjang elektroda pada reaktor mempengaruhi konsentrasi ozon, panjang elektroda 5, 10, 15, 20 dan $25 \mathrm{~cm}$ pada reaktor maka konsentrasi ozon yang dihasilkan semakin tinggi 624 ppm; dan (3) Elektroda dalam memiliki ketahanan terhadap korosi yang paling baik adalah elektoda yang terbuat dari stainless steel.

\section{DAFTAR PUSTAKA}

[1] Seydim ZG, Bever Jr. PI, dan Greene AK. Efficacy of ozone to reduce bacterial populations in the presence of food components. Food Microbiology. 2004; 21(4): 475-479.

DOI: $\underline{10.1016 / j . f m .2003 .10 .001}$

[2] Z Fang, Y Qiu, Y Sun, H Wang, Edmund K. Experimental study on discharge characteristics and ozone generation of dielectric barrier discharge in a cylindercylinder reactor and a wire-cylinder reactor Journal of Electrostatics. 2008; 66: 421-426. DOI: $10.1016 /$ j.elstat.2008.04.007

[3] Tae H Kim, Sung J Kim. Development of a helium flow sensor based on dielectric barrier discharge at atmospheric pressure. Sensors and Actuators A: Physical. 2011; 167(2): 297-303.

DOI: $10.1016 /$ j.sna.2011.02.054

[4] Teke S, Nur M, Winarni TA. Analisis Produksi Ozon dalam Reaktor Dielectric Barrier Discharge Plasma (DBDP) Terkait Panjang Reaktor dan Laju Alir Udara Serta Pemanfaatannya untuk Menjaga Kualitas Asam Amino Ikan. Berkala Fisika. 2014; 17(1): 25-32. Terdapat pada: http://ejournal.undip.ac.id/index.php/berkal a_fisika/article/view/6578

[5] Rakness K, et al. Guideline for Measurement of Ozone Concentration in the Process Gas from an Ozone Generator Science and Engineering. 1996; 18(3): 209-229.

DOI: $10.1080 / 01919519608547327$

[6] Syafrudin A, Novia. Produksi Ozon dengan Bahan Baku Oksigen Menggunakan Alat Ozon Generator. Jurnal Teknik Kimia. 2013; 19(2). Terdapat pada:

http://jtk.unsri.ac.id/index.php/jtk/article/vi ew/132

[7] Masschelein, W.J, Measurement of High Ozone Concentrations in Gases by KI Titration and Monitoring by UV-Absorption. (Also: on the Design of Idometric Washing Flasks) Ozone: Science and Engineering. 1998; 20(6): 489-493.

DOI: $10.1080 / 01919519809480355$

[8] Nur M, Restiwijaya M, dan Winarni TA. Dielectric barrier discharge plasma reactor analysis as ozone generator. International Symposium on Technology Management and Emerging Technologies. 2014; 129-132. DOI: 10.1109/ISTMET.2014.6936492 